\title{
Hungarian natural history under threat
}

\section{Historical collections given marching orders as government plans military university at museum site.}

\section{BY MARIAN TURNER}

$\mathrm{L}$ ooking for a new home: 200 human mummies from the eighteenth century, the remains of rare European dinosaurs and 10 million other artefacts currently at the Hungarian Natural History Museum, which is facing eviction later this year. The Hungarian government plans to turn the historic Budapest building given to the museum after the fall of communism in 1989 into a university to train the military or the police.

Scientists in Hungary and abroad are shocked by the move because the imposing 1836 Ludovika building has been extensively renovated for the

$\sum_{\text {I }}$ museum, and curators

로 are still moving the

collections in. They

$\underset{z}{\mathrm{~m}}$ say that the museum has not been offered an alternative site, and fear that the collections will have to be stored in crates until a new home is found.

"When the government announced the new university in February, they described the Ludovika as a long-neglected building. That came as a surprise to those of us who work there," says József Pálfy, a member

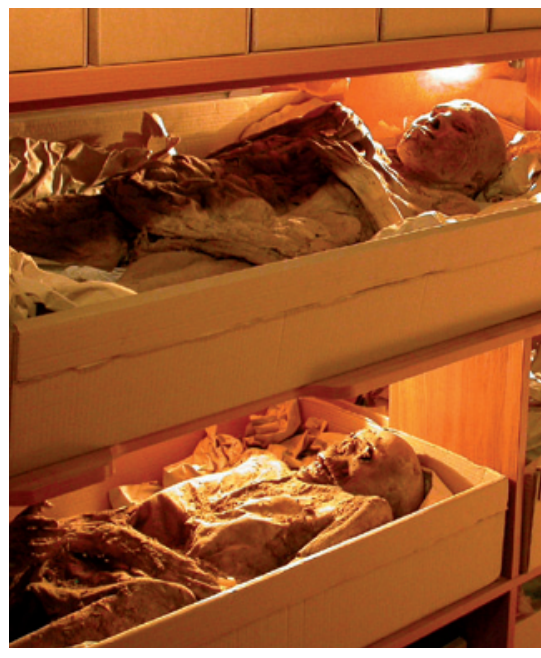

Museum's mummies seek new resting place. thought not to have lived in Europe.

The collections, some of which date back to 1802 , had been scattered around the city before the museum was granted the Ludovika buildings in the early 1990s. The buildings were in disrepair, but the Hungarian government invested around 10 billion forints (US\$53 million) to refurbish them. The buildings now give the museum 5,000 square metres of exhibition space, as well as modern research laboratories and three underground levels for storage.

András Jávor, state secretary for the Hungarian Ministry of National Resources, which is responsible for the museum, says that no jobs or resources will be lost in the reorganization, and that his ministry "is consulting with the museum about its future location”. But Attila Ösi, a palaeontologist in the same research group as Pálfy, whose discovery of the ceratopsian dinosaur fossils led to a Nature paper last year (A. Ösi et al. Nature 465, 466-468; 2010), says that research will suffer if they are forced to pack up their specimens again.

About 100 international researchers use the collections every year, and those of a joint research team between the museum's palaeontology research group and the Hungarian Academy of Sciences. But the government justifies its decision by saying that parts of the building need further renovations and that using the Ludovika for the new university is in keeping with tradition - the building contained a military academy until 1945.

The museum employs more than 70 scientists and publishes around 50 papers a year in international journals. In addition to the mummies - which were found in a church crypt in Vac in central Hungary and used to study the history of tuberculosis - it houses fossils found in western Hungary from ceratopsian dinosaurs, which were previously contacted by Nature echo the concerns of their Hungarian colleagues. "The collections at the museum are unique, and moving them again would create huge problems for multinational research collaborations," says Gareth Dyke, a palaeontologist at University College Dublin in Ireland, who is currently working at the museum.

Museum staff had just started to get comfortable at the Ludovika. "The scientists here are still spending time checking inventories to make sure all the objects have survived moving in," says Ösi. "After 200 years we got a central building for our museum," adds István Matskási, its director-general, "and now we do not know where we will have to go." 